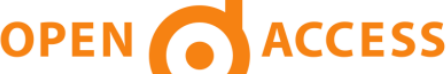 \\ International Journal of Social Sciences and Management \\ A Rapid Publishing Journal
}

ISSN 2091-2986

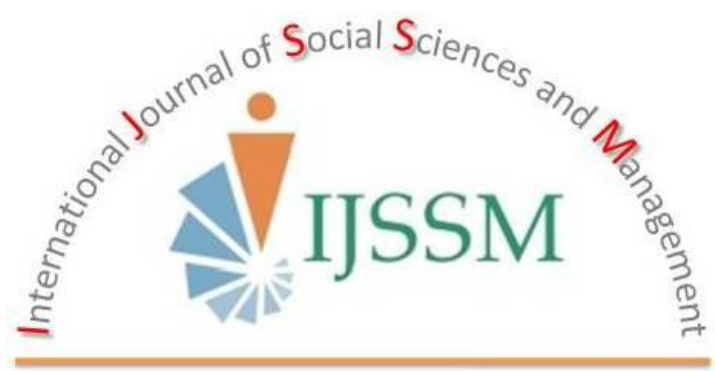

\section{Indexing and Abstracting}

CrossRef, Google Scholar, International Society of Universal Research in Sciences (EyeSource), Journal TOCs, New Jour, Scientific Indexing Services, InfoBase Index, Open Academic Journals Index (OAJI), Scholarsteer, Jour Informatics, Directory of Research Journals Indexing (DRJI), International Society for Research Activity (ISRA): Journal Impact Factor (JIF), Simon Fraser University Library, etc.

Vol-2(2) April, 2015

SEM-Biotech

Publishing

Impact factor : $\mathbf{3 . 3 8 9}$ 


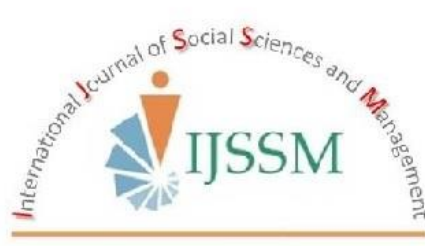

\title{
PARTICIPATION OF WOMEN IN DECISION MAKING IN GOAT REARING IN NADIA DISTRICT OF WEST BENGAL
}

\author{
Nirmal Kumar Tudu ${ }^{1 *}$ and Dulal Chandra Roy ${ }^{2}$ \\ ${ }^{I}$ Nadia Krishi Vigyan Kendra, Bidhan Chandra Krishi Viswavidyalaya, P.O.-Gayeshpur, Dist.-Nadia, West Bengal-741234, India \\ ${ }^{2}$ Department of Instructional Livestock Farm Complex, West Bengal University of Animal \& Fishery Sciences, Kolkata, West Bengal-700037, India \\ *Corresponding author email: drnktudu@gmail.com
}

\begin{abstract}
The present research work was done in Nadia district in the state of West Bengal during January, 2011 to December, 2013. From the study revealed that women were responsible for the tasks like taking the animals for grazing, fodder collection, chaffing and storage of fodder etc. Almost entire activities, so far as washing and cleaning of goat sheds and feeding of goats, were being performed by the women. Results indicated that the rural women participation in five blocks in breeding activities was found to be minor activities due to social mores and taboos in society. Analysis of the data revealed that women participation in health care activities was found to be minor activities due to lack knowledge regarding health care activities. The women in their late middle and old age actively participated in health care as they had learnt the things by seeing and out of experience. Most of the respondents interviewed were of the view that they require lot of training and knowledge with regard to the health care aspects. From the study it was seen that no women take decision without the permission of their spouse for selling the animals.
\end{abstract}

Key words: Women goat farmer; feeding; management; breeding; health care; marketing

\section{Introduction}

India is rich in goat population ( $16.7 \%$ of world share) and its genetic biodiversity (FAO, 2010). On the other hand, the state of West Bengal has the $2^{\text {nd }}$ highest goat population (150.69 lakh, All India Livestock Census, 18th, 2007) in the country (with $10.7 \%$ of the country's share). In rural areas goat keeping generates employment at the rate of $4.2 \%$ per annum (Dhara et al., 2008). Goats are considered as the fixed deposits for the poorest of the poor supplying fund as and when necessary by virtue of their ready market demand (Sahoo et al., 2004). The role of women in goat keeping is very significant in the rural families and goat is the most important means through which rural women are able to contribute meaningfully to the cash needs for her and their family members. Keeping in view of its association " a front line demonstration on feeding and housing management systems of goat rearing" is being initiated by Nadia Krishi Vigyan Kendra, Bidhan Chandra Krishi Viswavidyalaya, Gayeshpur, Nadia with specific objective to assess the participation and decision making of rural women in goat rearing activities.

\section{Materials and methods}

The present research work was done in Nadia district in the state of West Bengal during January, 2011 to December, 2013. The district Nadia is selected purposively. It lies between $22^{\circ} 52^{`} 30^{\prime \prime}$ and $24^{\circ} 05^{` 4}$ " parallels of North latitudes and $22^{\circ} 08^{\prime} 10^{\prime \prime}$ and $88^{\circ} 48^{\prime} 15^{\prime \prime}$ "meridians of East Longitudes. One village of each of the five blocks has been considered for this study. From each of the selected villages, 25 women goat keepers have been selected randomly. In this way 125 women goat keepers have been selected from five villages of the five blocks which have been constituted the sample of the present study. The climate of Nadia district is characterized by an oppressive hot summer, high humidity all the year round and well distributed rainfall (annual average rainfall $1419 \mathrm{~mm}$ ). Average daily maximum temperature is $31.8^{\circ} \mathrm{C}$, and minimum temperature is $21.3^{\circ} \mathrm{C}$ during the period of study. Humidity is high throughout the year, average being $61.5 \%$ (minimum) to $92.9 \%$ (maximum). The study area is located in hot-humid zone having three distinct seasons, viz., summer (March to June), monsoon (July to October) and winter (November to February). A pilot study has been carried out, and accordingly a structured interview schedule has been constructed. The data has been collected through face-to-face interview and by direct observation method. Data pertaining to women goat farmers' participation in decision making; viz., feeding, management, breeding, health care and marketing were recorded. Data were analyzed following the standard statistical methods (Snedecor and Cochran, 1967). 


\section{Results and Discussion}

Distribution of the women on the basis of their participation in goat rearing in five blocks of Nadia district of West Bengal

Distribution of the women on the basis of their participation in goat rearing in five blocks of Nadia district of West Bengal is presented in Table 1.

\section{Haringhata Block}

Analysis of the data revealed that women members of farmers' family played a major role in feeding (72 per cent) and management (64 per cent) in the rearing of goats in Haringhata Block of Nadia district of West Bengal. Results indicated that 28 per cent of farm women were actively involved in breeding of animals. The study revealed that 20 per cent rural women were engaged in health care of animals. In the study area only 8 per cent women members were involved in marketing regarding selling or purchasing of goats (Table 1).

\section{Chakdah Block}

Analysis of the data revealed that women members of farmers' family played a major role in feeding (84 per cent) and management (68 per cent) in the rearing of goats in Chakdah Block of Nadia district of West Bengal. Results indicated that 24 per cent of farm women were actively involved in breeding of animals. The study revealed that 16 per cent rural women were engaged in health care of animals. In the study area only 12 per cent women members were involved in marketing regarding selling or purchasing of goats (Table 1).

\section{Ranaghat-I Block}

Analysis of the data revealed that women members of farmers' family played a major role in feeding ( 84 per cent) and management (76 per cent) in the rearing of goats in Ranaghat-I Block of Nadia district of West Bengal. Results indicated that 20 per cent of farm women were actively involved in breeding of animals. The study revealed that 16 per cent rural women were engaged in health care of animals. In the study area only 8 per cent women members were involved in marketing regarding selling or purchasing of goats (Table 1).

\section{Ranaghat-II Block}

Analysis of the data revealed that women members of farmers' family played a major role in feeding ( 88 per cent) and management (60 per cent) in the rearing of goats in Ranaghat-II Block of Nadia district of West Bengal. Results indicated that 28 per cent of farm women were actively involved in breeding of animals. The study revealed that 20 per cent rural women were engaged in health care of animals. In the study area only 12 per cent women members were involved in marketing regarding selling or purchasing of goats (Table 1).

Table 1: Distribution of the women on the basis of their participation in goat rearing in five blocks of Nadia district of West Bengal

\begin{tabular}{|c|c|c|c|c|}
\hline Sl. No. & Name of the block & Activities & Number & Percentage $(\%)$ \\
\hline \multirow{5}{*}{1.} & \multirow{5}{*}{ Haringhata } & Feeding & 18 & 72.00 \\
\hline & & Management & 16 & 64.00 \\
\hline & & Breeding & 7 & 28.00 \\
\hline & & Health care & 5 & 20.00 \\
\hline & & Marketing & 2 & 8.00 \\
\hline \multirow{5}{*}{2.} & \multirow{5}{*}{ Chakdah } & Feeding & 21 & 84.00 \\
\hline & & Management & 17 & 68.00 \\
\hline & & Breeding & 6 & 24.00 \\
\hline & & Health care & 4 & 16.00 \\
\hline & & Marketing & 3 & 12.00 \\
\hline \multirow{5}{*}{3.} & \multirow{5}{*}{ Ranaghat-I } & Feeding & 21 & 84.00 \\
\hline & & Management & 19 & 76.00 \\
\hline & & Breeding & 5 & 20.00 \\
\hline & & Health care & 4 & 16.00 \\
\hline & & Marketing & 2 & 8.00 \\
\hline \multirow{5}{*}{4.} & \multirow{5}{*}{ Ranaghat-II } & Feeding & 22 & 88.00 \\
\hline & & Management & 15 & 60.00 \\
\hline & & Breeding & 7 & 28.00 \\
\hline & & Health care & 5 & 20.00 \\
\hline & & Marketing & 3 & 12.00 \\
\hline \multirow{5}{*}{5.} & \multirow{5}{*}{ Hanskhali } & Feeding & 20 & 80.00 \\
\hline & & Management & 19 & 76.00 \\
\hline & & Breeding & 6 & 24.00 \\
\hline & & Health care & 4 & 16.00 \\
\hline & & Marketing & 2 & 8.00 \\
\hline
\end{tabular}




\section{Hanshkhali Block}

Analysis of the data revealed that women members of farmers' family played a major role in feeding ( 80 per cent) and management (76 per cent) in the rearing of goats in Ranaghat-II Block of Nadia district of West Bengal. Results indicated that 24 per cent of farm women were actively involved in breeding of animals. The study revealed that 16 per cent rural women were engaged in health care of animals. In the study area only 8 per cent women members were involved in marketing regarding selling or purchasing of goats (Table 1).

From the study revealed that women were responsible for the tasks like taking the animals for grazing, fodder collection, chaffing and storage of fodder etc. Almost entire activities, so far as washing and cleaning of goat sheds and feeding of goats, were being performed by the women. Results indicated that the rural women participation in all blocks in breeding activities was found to be minor activities due to social mores and taboos in society. Analysis of the data revealed that women participation in health care activities was found to be minor activities due to lack of knowledge regarding health care activities. The women in their late middle and old age actively participated in health care as they had learnt the things by seeing and out of experience. Most of the respondents interviewed were of the view that they require lot of training and knowledge with regard to the health care aspects. From the study it was seen that no women take decision without the permission of their spouse for selling the animals. The present finding is supported by the earlier workers (Nandi et al., 2011; Samanta et al., 2009). Arshad et al. (2013) reported that women contribute in livestock management activities in addition to their routine household duties. Chauhan (2011) observed that farm women took a self-decision for decoration of house $(79.17 \%)$ and selection and preparation of food $(70.83 \%)$ in case of home management. Raut (2004) observed that $40 \%$ or more of total time on animal husbandry activities was contributed by female family members. Narmatha et al. (2009) reported that level of participation of women in livestock farming activities, actual doing of the work was more in management (85.5\%), feeding $(79.66 \%)$, health care $(68.66 \%)$ and breeding $(61.32 \%)$. But their actual participation was very low in marketing, selection of livestock enterprises, availing credit facilities and record maintenance. Upadhyay and Desai (2011) reported that farm women took independent decisions in the aspects of fodder management and milking whereas decisions in respect of economic aspects were taken jointly with their male counterparts. The participation was observed more in the aspects related to milking, feeding, health care and management, breeding and less in general aspect of animal husbandry. Kumar and Prajapati (2011) reported that farm women had poor knowledge status about the vaccination and other technical issues of the business as they were inadequately exposed to media, technical information and trainings. Tyagi et al. (2014) reported that women plays important roles in most of the activities, viz., management, nutrition, health, reproduction and breeding, economics and marketing related to goat rearing but management and financial sharing from goat rearing remain their prime activities. Shetter et al. (2005) reported that participation of the women was found to slightly higher in regular activities than in the health activities, followed by marketing activities. Number of mandays consumed by regular activities was maximum, which was followed by health activities and marketing activities. Regarding decision making pattern, the decisions were made by wife alone in the activities; caring the animals and fixing the time of milking. Rajkumar and Kavithaa (2014) reported that rural men were actively involved in health care, decision making and cash generating activities like taking sick animals for medical treatment (93.33 per cent), caring animals for breeding (86.66 per cent), taking the male kids for castration ( 85 per cent) and marketing of animals (81.66 per cent).

\section{Conclusion}

From the present study it can be concluded that women were responsible for the tasks like taking the animals for grazing, fodder collection, chaffing and storage of fodder etc. Almost entire activities, so far as washing and cleaning of goat sheds and feeding of goats, were being performed by the women. Participation of women in breeding activities was found to be minor activities due to social mores and taboos in society. Participation of women in health care activities was found to be minor activities due to lack of knowledge regarding health care activities. From the study no women take decision without the permission of their spouse for selling the animals.

\section{References}

$18^{\text {th }}$ All India Livestock Census (2007) Department of Animal Husbandry, Dairying \& Fisheries, Ministry of Agriculture, Govt. of India, New Delhi.

Arshad S, Muhammad S and Ashraf I (2013) Women's participation in livestock farming activities. The J. Anim. Plant Sci. 23: 304-308.

Chauhan NM (2011) Role performance of tribal farm women in agricultural and animal husbandry in Gujarat. Karnataka J. Agri. Sci. 24: 672-674.

Dhara KC, Ray N, Roy S, Samanta AK and Senapati PK (2008) Improvement of reproductive performances of Black Bengal goat through selection under field condition. $J$. Anim. Vet. Adv. 7: 599-603.

Kumar S and Prajapati CR (2011) Quantification of involvement of farm women in animal husbandry and dairy based farming system. J. Comm. Mobili. Sustain. Dev. 6: 190193. 
Nandi D, Roy S, Bera S, Kesh SS and Samanta AK (2011) The rearing system of Black Bengal goat and their farmers in West Bengal, India. Vet. World 4: 254-257.

Narmatha N, Uma V, Arun L and Geetha R (2009) Level of participation of women in livestock farming activities. Tamil Nadu J. Vet. Anim. Sci. 5: 4-8

Rajkumar NV and Kavithaa NV (2014) Work contribution of rural farm women in goat rearing practices in Erode district of Tamil Nadu. Int. J. Sci. Env. Tech. 3: 2076-2080.

Raut KC (2004) Estimation of woman labour in animal husbandry activities. J. Indi. Soci. Agri. Stat. 57: 171-177.

Sahoo AK, Pan S, Tantia MS and Ahlawat SPS (2004) Bengal goat. National agricultural technology project (Mission Mode) West Bengal University of Animal \& Fishery Science, Kolkata, West Bengal and National Bureau of Animal Genetic Resources, Karnal, Haryana, 1-63.

Samanta AK, Rai B and Senapati PK (2009) Black Bengal goat. AICRP on Goat improvement; Black Bengal Field Unit,
Kolkata, West Bengal University of Animal \& Fishery Sciences, Kolkata, West Bengal and Central Institute for Research on Goats, Makhdoom, Farah, Uttar Pradesh, 1-66.

Shetter SS, Badiger C and Mulla J (2005) Rural women engaged in goat rearing enterprise and their socio-economic characteristics. Karnataka J. Agri. Sci. 18:1058-1064.

Snedecor GW and Cochran WG (1967) Statistical Methods. $8^{\text {th }}$ Edn., The Iowa State University Press, Ames, Iowa, USA.

Tyagi KK, Patel MD, Sorathiya LM, Fulsoundar AB, Raval A, Kshirsagar DP, Jadav S and Thakor R (2014) Perceived role of women in goat rearing on agreement scale. Livestock Res. Int. 2: 87-90.

Upadhyay S and Desai CP (2011) Participation of farm women in animal husbandry in Anand district of Gujarat. $J$. Coтmu. Mobili. Sustain. Dev. 6: 117-121. 